\title{
Android-based capacitor discharging calculator application
}

\author{
Wisnu Kartika, Erika Loniza, Meilia Safitri \\ Department of Medical Electronics Technology, Vocational Program, Universitas Muhammadiyah Yogyakarta, \\ Indonesia
}

\section{Article Info}

Article history:

Received Feb 25, 2020

Revised Jan 18, 2021

Accepted Mar 1, 2021

Keywords:

Android

Application

Capacitor

Software

\begin{abstract}
Nowadays, many people using smartphone to connet to her colleague. The electronic device using capacitor and transistor. The electronic device's size recently become smaller. The capacitor can be used to the most important function that is used to store the energy and on the DC system is used to decrease the ripple from AC source. This research purpose build an apps which can calculate the charge remaining inside the capacitor. The method is using RC time constant. This research work well and can work functionally.
\end{abstract}

This is an open access article under the CC BY-SA license.

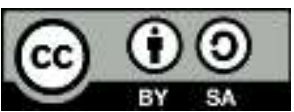

Corresponding Author:

Wisnu Kartika

Department of Medical Electronics Technology

Universitas Muhammadiyah Yogyakarta

Jl. Brawijaya, Tamantirto, Kasihan, Bantul, Daerah Istimewa Yogyakarta, Indonesia

Email: wisnu2007@umy.ac.id

\section{INTRODUCTION}

There are two type of electronic component that is active and passive component [1], [2]. The passive component is resistor, capacitor and inductor [3], [4]. The active component is diode and transistor. The capacitor can be used on the amplifier and the rectifier. The capacitor can save the energy [5], [6]. The wrapped capacitor there are many information about the charge and the voltage of the capacitor [7]-[11]. The capacitor can be divided into two types that is the polar capacitor and the nonpolar capacitor [12], [13]. There are several kinds of capacitor that is mylar, ELCO and ceramic [14], [15].

The capacitor implementation is on smartphone charger [16]-[21]. On the other hand, the capacitor can reduce the ripple of the rectifier output. The capacitor will keep the energy storage for certain time. The capacitor charge can be calculated by using this apps [22]-[29], the app will calculate the charge remain inside the capacitor. It will proposed the new scheme that can help the technician to calculate capacitor charge inside the capacitor using Android apps. It will explain the research into several section that is the introduction, research method and results and conclusions.

\section{RESEARCH METHOD}

From the previous research is proposed a new scheme that the apps can be used to calculate the charging and discharging the capacitor. It will show the remain charge inside the capacitor. The MIT app Inventor 2 is used to design this application, as shown Figure 1 and 2 . This application is used to calculate the charging and discharging the capacitor. 


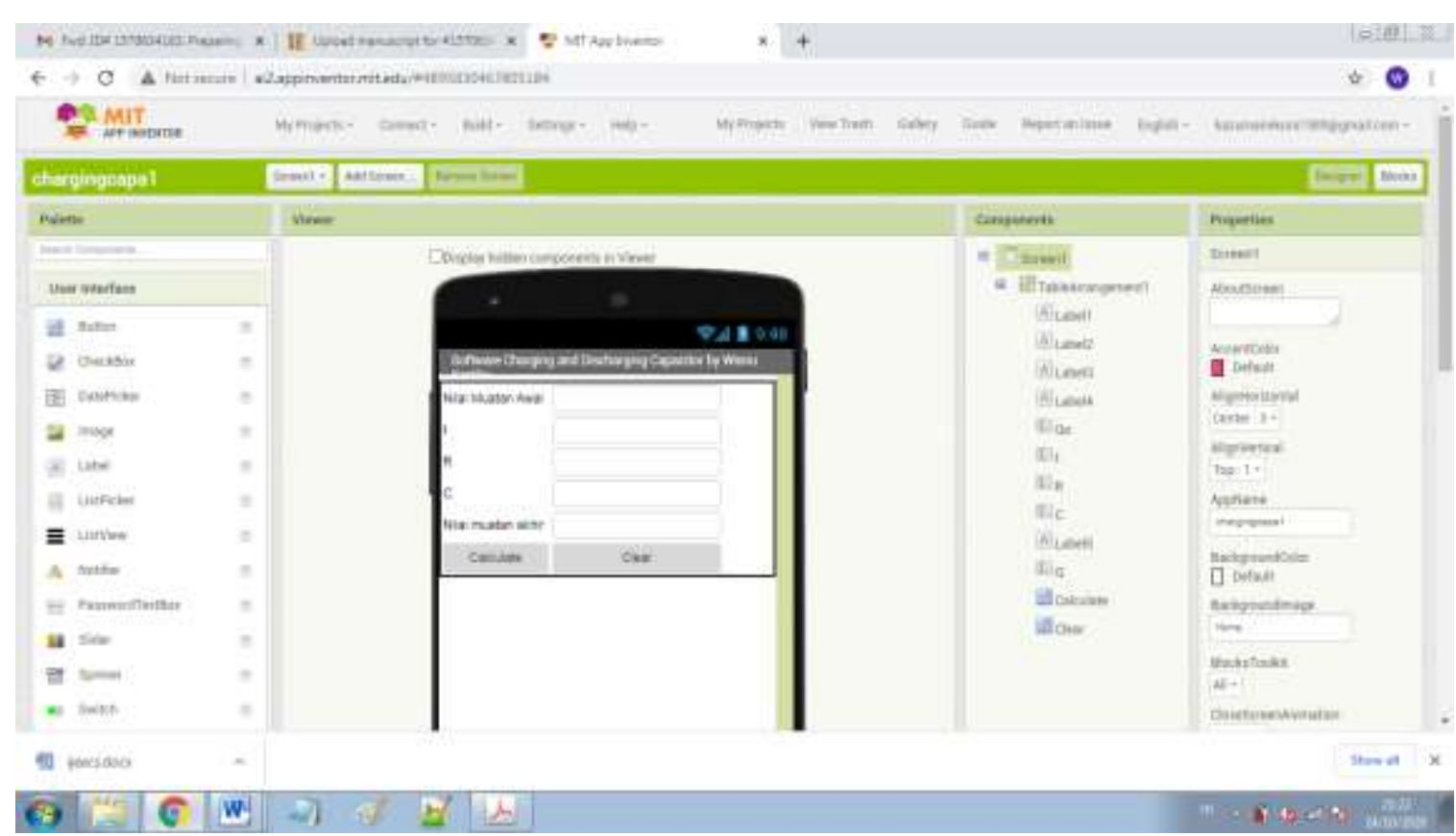

Figure 1. The software MIT app inventor 2

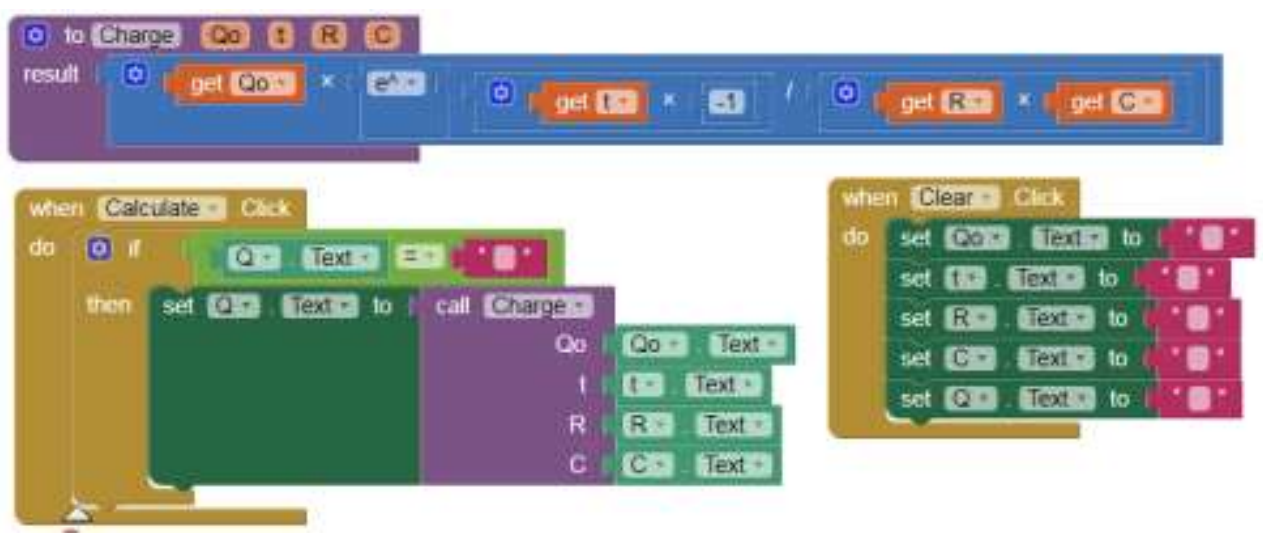

Figure 2. The app inventor 2 block code

The apps will be testing by inserting the value to the box. There are five boxes. Figure 3 shows the app design interface. The apps contain five boxes. The design is used by the laptop connected to the internet.

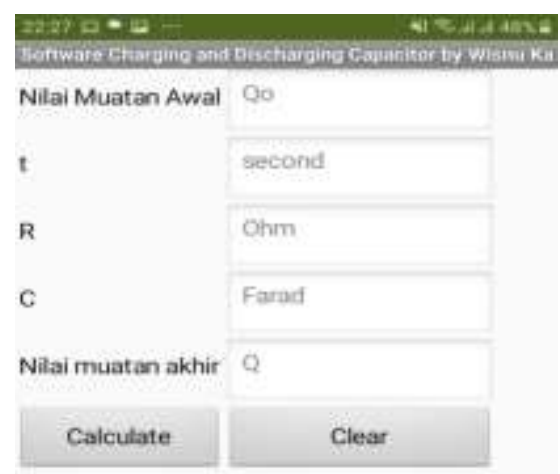

Figure 3. The proposed apps 


\section{RESULTS AND DISCUSSION}

This proposed apps using the Internet browser to running the apps. The MIT app inventor 2 will show the QR code. Then the QR code is scanned by the smartphone and it will display on the smartphone. It is inserted 10 coulombs to the first row. The charging time is inserted to the second row as shown in Figure 4. The capacitor and resistor value is $5 \mathrm{~F}$ and $2 \mathrm{Ohm}$. Then click the calculate button will show the remain charge inside the capacitor as shown at Figure 5. The calculation of this app can be seen in Figure 6 and 7 , with the calculated value of 6.06 coulomb. This app will be compared with the app desmos scientific calculator, available on Google Playstore.

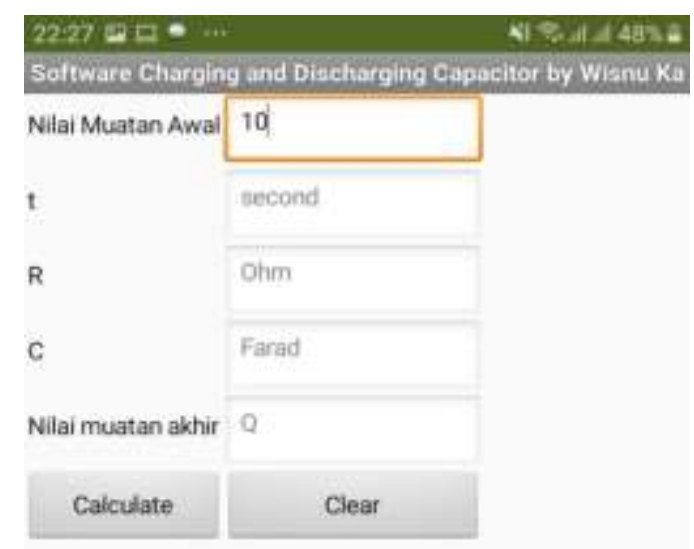

Figure 4. The charge value is inserted on the first row

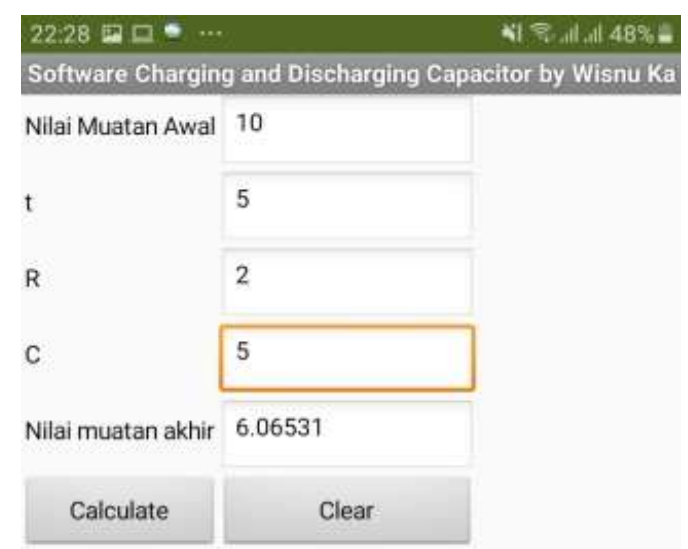

Figure 5. The display when the app is running

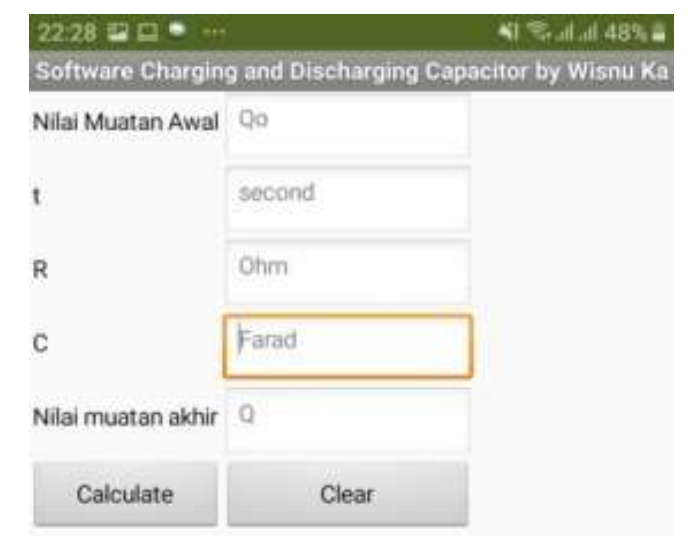

Figure 6. When clear button is clicked

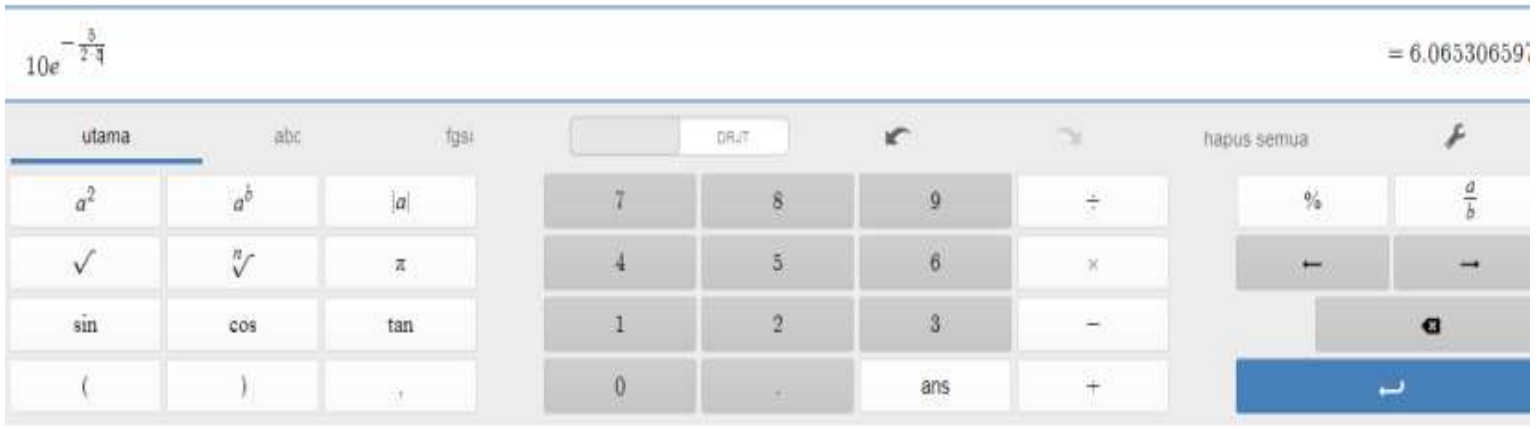

Figure 7. Calculation on desmos app (web version) as comparator 


$$
Q=Q_{0} e^{-\frac{t}{R C}}
$$

this Table 1.

By using this equation, the overall calculation can be shown. The value of the parameter is shown in

Table 1. The testing

\begin{tabular}{ccc}
\hline The Parameter & The Value & The Notation \\
\hline Q & 10 & Coulomb \\
t & 5 & second \\
R & 2 & Ohm \\
C & 5 & Farad \\
\hline
\end{tabular}

It can be calculated as: $Q=Q_{o} e^{-\frac{t}{R C}}$

On the Equation can be seen on the list below.

$\mathrm{Q}$ is the last charge, $\mathrm{Q}_{\mathrm{o}}$ is the early charge, and $\mathrm{t}$ is the charging time. (it can be both the charging time or the discharging time). $\mathrm{R}$ is the resistor value. $\mathrm{C}$ is the capacitor value.

$$
Q=10 e^{-\frac{5}{2 \times 5}}=6.06
$$

\section{CONCLUSION}

From our research, the proposed scheme can be concluded that the apps work well. Despite the several errors during the research, it could be fixed by using the software.

\section{ACKNOWLEDGEMENTS}

We thank all lecturers and staff of the Department of Medical Electronics Technology. Also, our gratitude is to my mother, father and wife and our friends who help me to write this paper, as well as our team on Medical Electronics Technology Universitas Muhammadiyah Yogyakarta.

\section{REFERENCES}

[1] A. M. Don Africa, S. T. Claire Alberto, and T. Y. Evan Tan, "Development of a portable electronic device for the detection and indication of fireworks and firecrackers for security personnel," Indones. J. Electr. Eng. Comput. Sci., vol. 19, no. 3, pp. 1194-1203, 2020, doi: 10.11591/ijeecs.v19.i3.pp.

[2] A. M. M. Asry, F. Mustafa, S. Y. Sim, M. Ishak, and A. Mohamad, "Study on footstep power generation using piezoelectric tile," Indones. J. Electr. Eng. Comput. Sci., vol. 15, no. 2, pp. 593-599, 2019, doi: 10.11591/ijeecs.v15.i2.pp593-599.

[3] T. S. Gunawan, A. Mutholib, and M. Kartiwi, "Performance evaluation of automatic number plate recognition on android smartphone platform," Int. J. Electr. Comput. Eng., vol. 7, no. 4, pp. 1973-1982, 2017, doi: 10.11591/ijece.v7i4.pp1973-1982.

[4] W. C. W. Lim, A. S. B. A. Ghafar, N. N. H. Rozi, and F. A. Saparudin, "Wireless water usage monitoring system for home/small premises," Indones. J. Electr. Eng. Comput. Sci., vol. 15, no. 2, pp. 704-713, 2019, doi: 10.11591/ijeecs.v15.i2.pp704-713.

[5] B. V. Rajanna and M. K. Kumar, "Dynamic model development for lead acid storage battery," Indones. J. Electr. Eng. Comput. Sci., vol. 15, no. 2, pp. 609-619, 2019, doi: 10.11591/ijeecs.v15.i2.pp609-619.

[6] Z. Dzulkurnain, A. K. Mahamad, S. Saon, M. A. Ahmadon, and S. Yamaguchi, "Internet of things (IoT) based traffic management \& routing solution for parking space," Indones. J. Electr. Eng. Comput. Sci., vol. 15, no. 1, pp. 336-345, 2019, doi: 10.11591/ijeecs.v15.i1.pp336-345.

[7] Darwison et al., "A leakage current estimation based on thermal image of polymer insulator," Indones. J. Electr. Eng. Comput. Sci., vol. 16, no. 3, pp. 1096-1106, 2019, doi: 10.11591/ijeecs.v16.i3.pp1096-1106.

[8] S. DasMahapatra, I. Gandhi, K. Nair, and S. N. Sharan, "Sensing schedule optimization to minimize interference with primary users in cognitive radio network," Indones. J. Electr. Eng. Comput. Sci., vol. 17, no. 3, pp. 1399-1404, 2019, doi: 10.11591/ijeecs.v17.i3.pp1399-1404.

[9] M. R. B. M. Shariff, M. F. L. Abdullah, M. Y. B. A. Latiff, A. B. Mohamad, and I. B. Ismail, "Detecting leakage current by infrared thermography method," Indones. J. Electr. Eng. Comput. Sci., vol. 16, no. 1, pp. 200-207, 2019, doi: 10.11591/ijeecs.v16.i1.pp200-207. 
[10] L. Velusamy et al., "Global system for mobile communication based domestic electrical load control using arduino uno,” Indones. J. Electr. Eng. Comput. Sci., vol. 16, no. 1, pp. 342-348, 2019, doi: 10.11591/ijeecs.v16.i1.pp342348.

[11] N. A. Wahab, M. N. Md Tan, and M. N. Hushim, "Closed-loop ring resonator topology for bandpass filter applications," Indones. J. Electr. Eng. Comput. Sci., vol. 17, no. 3, pp. 1422-1426, 2019, doi: 10.11591/ijeecs.v17.i3.pp1422-1426.

[12] M. J. Tahir, B. A. Bakar, M. M. Alam, and M. S. U. Mazlihum, "Optimal capacitor placement in a distribution system using ETAP software,” Indones. J. Electr. Eng. Comput. Sci., vol. 15, no. 2, pp. 650-660, 2019, doi: 10.11591/ijeecs.v15.i2.pp650-660.

[13] R. S. Selvarajan, B. Y. Majlis, N. Yusof, and A. A. Hamzah, "Channel length scaling and electrical characterization of graphene field effect transistor (GFET)," Indones. J. Electr. Eng. Comput. Sci., vol. 15, no. 2, pp. 697-703, 2019, doi: 10.11591/ijeecs.v15.i2.pp697-703.

[14] U. Narayanan, V. Paul, and S. Joseph, "A novel approach to big data analysis using deep belief network for the detection of android malware," Indones. J. Electr. Eng. Comput. Sci., vol. 16, no. 3, pp. 1447-1454, 2019, doi: 10.11591/ijeecs.v16.i3.pp1447-1454.

[15] S. N. Al-Bargothi, G. M. Qaryouti, and Q. M. Jaber, "Speed control of DC motor using conventional and adaptive PID controllers," Indones. J. Electr. Eng. Comput. Sci., vol. 16, no. 3, pp. 1221-1228, 2019, doi: 10.11591/ijeecs.v16.i3.pp1221-1228.

[16] R. F. Rahmat, S. Purnamawati, H. Saito, M. F. Ichwan, and T. M. Lubis, "Android-based automatic detection and measurement system of highway billboard for tax calculation in Indonesia," Indones. J. Electr. Eng. Comput. Sci., vol. 14, no. 2, pp. 877-886, 2019, doi: 10.11591/ijeecs.v14.i2.pp877-886.

[17] Z. M. Yusof, M. M. Billah, and K. Kadir, "Real-time water quality monitoring system: An IoT application," Indones. J. Electr. Eng. Comput. Sci., vol. 15, no. 1, pp. 178-182, 2019, doi: 10.11591/ijeecs.v15.i1.pp178-182.

[18] R. Ramly, A. A. B. Sajak, and M. Rashid, "IoT recycle management system to support green city initiatives," Indones. J. Electr. Eng. Comput. Sci., vol. 15, no. 2, pp. 1037-1045, 2019, doi: 10.11591/ijeecs.v15.i2.pp10371045.

[19] A. N. Azlina, A. B. Zanariah, and Y. Faridah, "Intelligent home automated system," Indones. J. Electr. Eng. Comput. Sci., vol. 15, no. 2, pp. 733-742, 2019, doi: 10.11591/ijeecs.v15.i2.pp733-742.

[20] H. R. Fajrin, R. N. Adnan, M. Irfan, and I. P. Sari, "Electronic Snellen Chart with Bluetooth Connection and Smartphone App," IOP Conf. Ser. Mater. Sci. Eng., vol. 851, no. 1, 2020, doi: 10.1088/1757-899X/851/1/012018.

[21] I. P. Sari and H. R. Fajrin, "Mobile augmented reality using cloud database for interactive museum guiding system,” J. Phys. Conf. Ser., vol. 1193, no. 1, 2019, doi: 10.1088/1742-6596/1193/1/012030.

[22] A. Setiawan, S. Rostianingsih, and T. R. Widodo, "Augmented reality application for chemical bonding based on android,” Int. J. Electr. Comput. Eng., vol. 9, no. 1, p. 445, 2019, doi: 10.11591/ijece.v9i1.pp445-451.

[23] I. Riadi, R. Umar, and A. Firdonsyah, "Forensic tools performance analysis on android-based blackberry messenger using NIST measurements," Int. J. Electr. Comput. Eng., vol. 8, no. 5, pp. 3991-4003, 2018, doi: 10.11591/ijece.v8i5.pp3991-4003.

[24] H. A. Alkaaf, A. Ali, S. M. Shamsuddin, and S. Hassan, "Exploring permissions in android applications using ensemble-based extra tree feature selection," Indones. J. Electr. Eng. Comput. Sci., vol. 19, no. 1, p. 543, 2020, doi: 10.11591/ijeecs.v19.i1.pp543-552.

[25] T. Rasul, R. Latif, and N. S. M. Jamail, "A computational forensic framework for detection of hidden applications on android," Indones. J. Electr. Eng. Comput. Sci., vol. 20, no. 1, pp. 353-360, 2020, doi: 10.11591/ijeecs.v20.i1.pp353-360.

[26] F. I. Khan, Y. Javed, and M. Alenezi, "Security assessment of four open source software systems," Indones. J. Electr. Eng. Comput. Sci., vol. 16, no. 2, pp. 860-881, 2019, doi: 10.11591/ijeecs.v16.i2.pp860-881.

[27] A. K. Jassim and R. H. Thaher, "Calculate the optimum slot area of elliptical microstrip antenna for mobile application," Indones. J. Electr. Eng. Comput. Sci., vol. 16, no. 3, pp. 1364-1370, 2019, doi: 10.11591/ijeecs.v16.i3.pp1364-1370.

[28] S. R. Hamidi, M. A. Muhamad Yusof, S. M. Shuhidan, and S. A. Kadir, "Ir4.0: Unmanned store apps," Indones. J. Electr. Eng. Comput. Sci., vol. 17, no. 3, pp. 1540-1547, 2019, doi: 10.11591/ijeecs.v17.i3.pp1540-1547.

[29] S. M. Norzeli, I. Ismail, N. M. Din, M. T. Ali, A. A. Almisreb, and A. A. Alkahtani, "A rectangular CSRR based microstrip UHF reader patch antenna for RFID applications," Indones. J. Electr. Eng. Comput. Sci., vol. 17, no. 3, pp. 1434-1441, 2019, doi: 10.11591/ijeecs.v17.i3.pp1434-1441. 